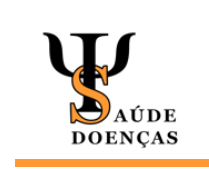

Revista Psicologia, Saúde \& Doenças

Vol. 22, $\mathrm{N}^{\circ}$. 3, 828-843, 2021

Sociedade Portuguesa de Psicologia da Saúde
ISSN 2182-8407

www.sp-ps.pt

https://doi.org/10.15309/21psd220305

\title{
ADAPTATION AND VALIDATION OF THE FEAR OF COVID-19 SCALE FOR FACE- TO-FACE LEARNING
}

\section{ADAPTAÇÃO E VALIDAÇÃO DA ESCALA DO MEDO DO COVID-19 NAS AULAS PRESENCIAIS}

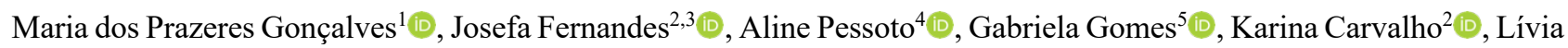

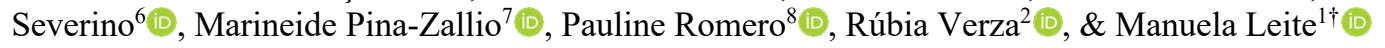

\begin{abstract}
${ }^{1}$ CESPU - Institute of Research and Advanced Training in Health Sciences and Technologies, Paredes, Portugal, mprazeres.goncalves@iucs.cespu.pt,manuela.leite@iucs.cespu.pt

${ }^{2}$ UNILAGO - Union of Colleges of the Great Lakes - Medical School, São Jose do Rio Preto, São Paulo, Brazil, josefadiassf@gmail.com,kaka_fc_73@hotmail.com,rubia.pv@icloud.com

${ }^{3}$ Brazilian Society of Psychoanalysis of São Paulo, São Paulo, Brazil

${ }^{4}$ Unorp -University Center North of the State of São Paulo, São José do Rio Preto, São Paulo, Brazil, alinebppsico@gmail.com

${ }^{5}$ NSU - Nova Southeastern University, Florida, USA, gabrielacostantini19@gmail.com

${ }^{6}$ Polytechnic and Arts University of Paraguay, Pedro Juan Caballero, Paraguay, liviars_pba@hotmail.com

${ }^{7}$ Psychology Neuroscience of Mental Health at the King's College London. NHS - Sussex Partnership - Bank Mental Health Support Worker, London, UK, marineidepinna@gmail.com

${ }^{8}$ Marcel Bienfait School of Manual Therapy, Roma, Italy, lineromero@hotmail.com
\end{abstract}

Resumo: A COVID-19 tem tido grandes repercussões no ensino superior, devido ao medo de contágio. O presente estudo tem como objetivo apresentar uma versão adaptada da FCV-19S de Ahorsu et al. (2020), ao contexto de aulas presenciais: Fear of COVID 19 Scale, to Presencial Lessons (FCV-19S-PL). A FCV-19S foi traduzida para português e adaptada ao contexto das aulas presenciais, tendo resultado numa escala de 9 itens. A amostra é composta por 534 estudantes universitários. Foi utilizada a análise fatorial confirmatória e a análise de confiabilidade para determinar as propriedades psicométricas da escala. A FCV-19S-PL revelou uma boa fidelidade $(\alpha=$ 0,904 ), bem como uma boa consistência interna dos dois fatores (fator $1 \alpha=0,878$; fator $2 \alpha=0,842$. A FCV-19S-PL apresenta uma estrutura bidimensional com propriedades psicométricas robustas, sendo confiável e válida na avaliação do medo da COVID-19 no contexto específico de aulas presenciais.

Palavras-Chave: COVID-19; FCV-19S; Presential Lessons; University; Fear of COVID-19

\begin{abstract}
COVID-19 has had a great impact on higher education due to the fear of contagion. This study aims to present an adapted version of the Fear of COVID-19 Scale (FCV-19S) designed by Ahorsu et al. (2020) to the context of face-to-face learning: Fear of COVID-19 Scale for Face-toFace Learning (FCV-19S-FL). The FCV-19S was translated into European Portuguese and adapted to the context of face-to-face learning, resulting in a 9-item scale. The sample consists of 534 university students. An explanatory factor analysis and a reliability analysis were used to determine the psychometric properties of the scale. The FCV-19S-FL has demonstrated good reliability $(\alpha=$ 0.904 ) as well as good internal consistency of both factors (Factor $1 \alpha=0.878$; Factor $2 \alpha=0.842$ ). The FCV-19S-FL has a two-dimensional structure with robust psychometric properties and has
\end{abstract}

\footnotetext{
†Morada de Correspondência: CESPU, Instituto de Investigação e Formação Avançada em Ciências e Tecnologias da Saúde, Rua Central de Gandra, 1317, 4585-116 Gandra, Paredes, Portugal. Email: manuela.leite@iucs.cespu.pt

Submetido: 02 de setembro de 2021

Aceite: 10 de outubro de 2021
} 
Maria dos Prazeres Gonçalves, Josefa Fernandes, Aline Pessoto, Gabriela Gomes, Karina Carvalho, Lívia Severino, Marineide Pina-Zallio, Pauline Romero, Rúbia Verza, \& Manuela Leite

proved to be reliable and valid for the assessment of fear of COVID-19 in the specific context of faceto-face learning.

Keywords: COVID-19; FCV-19S; Face-to-Face Learning; University; Fear of COVID-19

Coronavirus disease 2019 (COVID-19) was first identified in the city of Wuhan, China, in December 2019, and quickly became the «major challenging global public health problem" (Phelan et al., 2020), having been declared a "public health emergency of international concern (PHEIC) on 30 January 2020" (WHO/Europe, 2020). On 7 June 2021, there were 172,956,039 confirmed cases of COVID-19, including 3,726,466 deaths worldwide (World Health Organization - WHO, n.d.).

The rapid evolution of COVID-19 pandemic forced several countries to adopt drastic containment measures, such as lockdown, quarantines, and closure of borders. The volatile nature of the coronavirus outbreak did not allow for a clear prediction of its duration, and each country gradually took overall containment measures as well as specific action related to educational facilities, keeping pace with the pandemic. School closure had an impact on $87 \%$ of students worldwide (UNESCO, 2020), confronting the education community with a new reality and the urgent need to adapt to it. Distance learning posed major challenges to students, and several studies highlighted a negative impact on students' mental health (e.g. Cao et al., 2020; Kaparounaki et al., 2020; Kecojevic et al., 2020; Zhou et al., 2020), particularly among university students (e.g. Araújo et al., 2020; BourionBédès et al., 2020; Dhar et al., 2020; Marelli et al., 2020). Stress, feelings of uncertainty (Al-Rabiaah et al., 2020; Araújo et al., 2020), depression and anxiety (Bourion-Bédès et al., 2020; Kaparounaki et al., 2020; Marelli et al., 2020; Odriozola-González et al., 2020; Zhou et al., 2020), sleep disorders (Marelli et al., 2020), worries (Kaparounaki et al., 2020) about career and the future (Dhar et al., 2020), and fear (Martínez-Lorca et al., 2020) were commonly observed during the quarantine period. Therefore, according to UNESCO (2020), "the COVID-19 pandemic has caused an unprecedented crisis in education and school closures across the globe" (UNESCO, 2020, p.5), estimating that about 24 million students (including pre-school to university), are at risk of dropping out of school in the 2020-2021 school year. Among the economic, cultural and social factors, fear that the virus reappears is identified as one of the risk factors for school dropout.

According to Shigemura et al. (2020), fear of the unknown is responsible for increasing overall levels of anxiety in the general population, and this was the first reaction to this global health emergency crisis. The rapid spread of the disease and its associated risks as well as the nature of the pandemic play a key role in increasing fears and worries (Ahorsu et al., 2020). Thus, considering the negative impact on mental health and the associated psychosocial challenges (e.g. stigmatization and discrimination), Ahorsu et al. (2020) developed a scale aimed at assessing individuals' fear of COVID-19 (Fear of COVID-19 Scale - FCV-19S), with the objective of “(...) providing valuable information on fear of COVID-19 as a way to facilitate public health initiatives on allaying public's fears" (Ahorsu et al., 2020, p.1). The final version of the Fear of COVID-19 Scale (FCV-19S) consists of seven items that assess fear of COVID-19. The scale is divided into two factors: Factor 1 (Items: 1, 2, 4 and 5) assesses Emotional Fear; and Factor 2 (Items: 3, 6, 7), Cognitive Fear. Respondents answer each item using a five-point Likert scale ("strongly disagree," "disagree," "neither agree nor disagree," "agree," and "strongly agree"), and "(...) higher overall scores on the FCV-19S indicate more severe fear of COVID-19" (Ahorsu et al., 2020). The results obtained by the authors demonstrate that the FCV-19S is a one-dimensional scale with robust psychometric properties and with comparable total values in both sexes and in different age groups (Ahorsu et al., 2020). The fact that the FCV-19S is " (...) a quick and easy-to-use tool that undergoes rigorous psychometric testing and appears to be suitable for both genders and all ages (...)" (Sakib et al., 2020, p. 2) led to its dissemination to multiple countries, translation into several languages and subsequent validation (e.g. 
Faro et al., 2020; Magano et al., 2021; Martínez-Lorca et al., 2020; Pang et al., 2020; Reznik et al., 2020; Sakib et al., 2020; Satici et al., 2020; Soraci et al., 2020).

Despite the relevance of the FCV-19S, it assesses overall fear with focus on the characteristics of the pandemic, and does not approach specific contexts, such as school classrooms and return to faceto-face classes in the midst of the coronavirus pandemic. After a period of lockdown/social isolation and the implementation of distance learning under unprecedented adverse circumstances (Araújo et al., 2020), a significant number of students started the new 2020-2021 academic year in the middle of a pandemic, which coincided with the surge of a second wave in some countries (e.g. Portugal, France, Italy). In an attempt to control the pandemic and, at the same time, to mitigate the negative impact of distance learning, several countries opted for a blended learning approach, namely online theoretical classes and face-to-face practical classes. Students returning to school faced a wide range of atypical measures, such as "(...) avoiding crowded/close contact environments as much as possible, respecting protective (social) distancing, wearing appropriate masks, hand hygiene, and some essential protective measurements of classrooms and environment" (Hacimustafaoğlu, 2020). Despite all containment efforts, the risk of contagion was not reduced to zero (Wrighton \& Lawrence, 2020), therefore it was not possible to return to normal. The number of students with SARS-CoV-2 infection gradually increased in the academic community.

Given the lack of studies investigating the return to face-to-face teaching, on the one hand, anxiety for socialization (Paltiel et al., 2020) among university students can be observed; on the other hand, symptoms associated with the psychological impact of confinement and distance learning may be reactivated. In the absence of vaccines, effective treatment, and herd immunity (Paltiel et al., 2020), re-opening university campuses and resuming classes in closed spaces may (re)activate the fear associated with the risk of transmission, morbidity, and mortality (Martínez-Lorca et al., 2020), despite the lower risk of severe disease among young people (Hacımustafaoğlu, 2020; Nathan et al., 2020; Vermund \& Pitzer, 2020; Walger et al., 2020). However, according to Martínez-Lorca et al. (2020), high levels of fear may interfere with their reasoning ability when confronted with COVID19. Thus, the main objective of this study is the adaptation and validation of the Fear of COVID-19 Scale (FCV-19S) to the specific context of face-to-face classes.

\section{METHODS}

Adaptation of the FCV-19S to the context of face-to-face learning: The Fear of COVID-19 Scale for Face-to-Face Learning (FCV-19S-FL)

The FCV-19S-FL was adapted from the FCV-19S, with the objective of evaluating the fear of COVID-19 among university students in the context of face-to-face learning, using a blended learning model, namely online theoretical classes and face-to-face practical classes. Permission was obtained from the original authors to adapt and validate the FCV-19S for face-to-face learning in a Portuguese population.

The first step consisted of the translation of the FCV-19S into European Portuguese, rigorous analysis of the scale developed by Ahorsu et al. (2020), followed by a literature review of the psychological impact of COVID on university students, which was supported by the extensive experience of some of the researchers in teaching at universities.

Next, the original version of the FCV-19S (Table 1) was adapted as follows: Item 1 was maintained; Items 2, 3, 5, 6, and 7 were adapted to the specific context of face-to-face classes at universities; Item 4 was significantly changed; and two new items were added. 
Table 1. Comparison between the items of the original scale (FCV-19S) and the adapted version (FCV-19SFL)

\begin{tabular}{|c|c|}
\hline FCV-19S Items & Adaptation of the FCV-19S for Face-to-Face Learning \\
\hline 1. I am most afraid of coronavirus-19. & 1. Tenho muito medo do COVID \\
\hline $\begin{array}{l}\text { 2. It makes me uncomfortable to think about } \\
\text { coronavirus-19. }\end{array}$ & 2. O regresso às aulas presenciais deixa-me desconfortável \\
\hline $\begin{array}{l}\text { 3. My hands become clammy when I think about } \\
\text { coronavirus-19. }\end{array}$ & $\begin{array}{l}\text { 3. Durante as aulas presenciais sinto as minhas mãos } \\
\text { húmidas/frias }\end{array}$ \\
\hline $\begin{array}{l}\text { 4. I am afraid of losing my life because of } \\
\text { coronavirus- } 19 \text {. }\end{array}$ & 4. Tenho muito medo de ser contagiado na faculdade \\
\hline $\begin{array}{l}\text { 5. When watching news and stories about } \\
\text { coronavirus- } 19 \text { on social media, I become } \\
\text { nervous or anxious. }\end{array}$ & $\begin{array}{l}\text { 5. Fico nervoso ou ansioso sempre que vejo/ouço noticias de } \\
\text { surtos nas faculdades }\end{array}$ \\
\hline $\begin{array}{l}\text { 6. I cannot sleep because I'm worrying about } \\
\text { getting coronavirus- } 19 \text {. }\end{array}$ & $\begin{array}{l}\text { 6. Tenho dificuldades em dormir na noite anterior às aulas } \\
\text { presenciais }\end{array}$ \\
\hline \multirow[t]{3}{*}{$\begin{array}{l}\text { 7. My heart races or palpitates when I think about } \\
\text { getting coronavirus- } 19 \text {. }\end{array}$} & $\begin{array}{l}\text { 7. O meu coração dispara sempre que um colega na sala de aula } \\
\text { espirra ou tosse }\end{array}$ \\
\hline & $\begin{array}{l}\text { 8. Sinto-me desconfortável com a realização de atividades (ex. } \\
\text { laboratoriais, trabalhos de grupo) que impliquem maior } \\
\text { proximidade com colegas }\end{array}$ \\
\hline & $\begin{array}{l}\text { 9. Tenho dificuldades em concentrar-me nas aulas presenciais, } \\
\text { devido ao medo de ser contagiado }\end{array}$ \\
\hline
\end{tabular}

Item 4 "I am afraid of losing my life because of coronavirus-19" was rephrased, replacing "fear of losing my life" with "fear of being infected at the university", considering national and international epidemiological data, which indicate low morbidity due to COVID-19 among young people, low mortality rates, and increased risk of infection among university students. In this context, it was considered more relevant to ask them about the risk of contagion - a more current and realistic concern compared to the fear of dying from COVID-19.

Two items were added to the original seven-item scale, namely "I feel uncomfortable with activities (e.g. laboratory, group work) that imply greater physical proximity to my fellow students" - Item 8; and "I have difficulty concentrating in face-to-face classes due to the fear of being infected" - Item 9. Item 8 intended to deepen the discomfort caused by the physical proximity to other students given the nature of the face-to-face classes; Item 9 aimed at measuring the potential impact on the ability to concentrate in class, considering that the fear of contagion may allocate attentional resources towards monitoring potential sources of danger (contagion).

The next step consisted of evaluating all nine items by an expert panel composed of university professors, psychologists, and university students, who confirmed the relevance of the questions by correcting minor grammatical errors. Then, in order to validate the instrument regarding clarity and understanding of the statements in each item, a pre-test was carried out: a questionnaire was administered to a convenience sample of 20 university students aged between 18 and 24 years (mean $=20.15 ; \mathrm{SD}=1.46$ ) in the classroom. Students were asked to complete the questionnaire online and were further asked about the clarity and relevance of the questions, confirming the relevance of continuing the validation study.

The final version of the questionnaire (Appendix A) encompassed nine items, which were answered using a five-point Likert scale: "strongly disagree", "disagree", "neither agree nor disagree", "agree", "totally agree". The total score ranges from 0 to 45, and higher scores represent greater fear.

This version was translated into Brazilian Portuguese (Appendix B), French (Appendix C), British English (Appendix D), Spanish (Appendix E), and Italian (Appendix F), having been administered in 
Portugal, Brazil, France, Paraguay, and England to obtain the study of the psychometric properties of the scale.

\section{Sample}

The sample of the present study included 534 university students attending different courses and in various Portuguese universities, aged between 17 and 46 years old $(M=20.24 ; S D=2.56)$, in which $404(75.7 \%)$ of participants were female and $129(24.2 \%)$ were male. Regarding the courses the students were enrolled in, $278(52.06 \%)$ students attended courses in the areas of health sciences, 123 (23.0\%) economics and social sciences, $81(15.2 \%)$ humanities, and $52(9.74 \%)$ engineering. Of the 534 students, 409 (76.6\%) attended public universities and $125(23.4 \%)$ private universities; 186 $(34.8 \%)$ were in the 2 nd year of the course, 152 (28.5\%) in the third year, $135(25.3)$ in the first year, $45(8.4 \%)$ in the fourth year, and $16(3.0 \%)$ in the fifth year.

One-hundred percent of the sample used blended learning, namely online theoretical classes and face-to-face practical classes.

\section{Procedure}

The FCV-19S-FL is part of the investigation protocol of an international project, coordinated from Brazil. Therefore, after its construction, the research project was submitted and approved by Brazilian Research Ethics Committee (No. 4,393,453).

As previously mentioned, the FCV-19S-FL was translated into several languages as well as administered via the Web in different countries (Portugal, Brazil, France, Paraguay, and England), using several links to access Google Forms (for each respective language).

This is a convenience sample collected using the "Snowball" method, where each researcher recruited future participants through social media and personal contacts (messages via WhatsApp, Messenger, Instagram, e-mail), informing about the purpose of the study, inviting them to participate and sharing the content of the study with their acquaintances at the university. Each individual who accepted to participate shared the link with their acquaintances and so on, providing subsequent referrals.

Importantly, participation in the study was voluntary; all subjects were informed of the objectives and purposes of the study and were asked to sign an informed consent prior completing the FCV19S-FL. All procedures were conducted in compliance with the ethical principles of the Declaration of Helsinki.

Taking into account the number of countries involved and the disparities in responses obtained in these countries, it was decided to carry out the initial and more in-depth study of the psychometric properties of the FCV-19S-FL with the sample collected in Portugal, as it obtained the largest number of participants. However, once the validity of the European Portuguese (Portugal) version was confirmed, the psychometric properties in the participating countries were studied. Data collection took place between 25 October and 30 November 2020.

\section{Data Analysis}

Data was analysed using the IBM $^{\circledR}$ SPSS Statistics software (Statistical Program for Social Sciences), version 27.0 for Windows.

Descriptive statistics were performed to estimate frequencies and percentages (categorical variables), means and SD (continuous variables) of the participants' sociodemographic characteristics. The internal consistency of the FCV-19S-FL was measured with Cronbach's Alpha and with the correlation between the question score and the overall assessment score. Construct 
validity was assessed through exploratory factor analysis (principal components) with varimax rotation. Sampling adequacy was confirmed using the Kaiser-Mayer-Olkin (KMO) measure, and the factor analysis was supported by Bartlett's test of sphericit $(p<0.05)$. The number of factors to retain was determined based on eigenvalue greater than 1 . The item-factor association was determined by the factor loading as an indication of the extent each item was associated with each factor.

\section{RESULTS}

Exploratory Factor Analysis (EFA) Results: The Fear of COVID-19 Scale for Face-to-Face Learning $(F C V-19 S-F L)$

For the total sample, the mean value of FCV-19S-FL was $22.99(S D=8.12)$, median $=22.0$ with variation of 9-45. The scale has shown good overall reliability with a high correlation of all items with the total of the scale, which indicates its good functioning as a whole and contributes to the high Cronbach's Alpha value (0.904) (Table 2).

Data screening results suggested that all nine items were suitable for the EFA (Tabachnick \& Fidell, 2013), with no problems related to sample size, missing data, non-normality, multicollinearity, or uniqueness. The correlation matrices were also favourable [Bartlett's test of sphericity $\chi^{2}(36)=$ $2689,253, p<0.001$, Kaiser Meyer-Olkin test $(\mathrm{KMO})=0.902)]$.

All nine items of the FCV-19S-FL were submitted to EFA with varimax rotation. The maximum likelihood factor analysis with a cut-off point of 0.40 and the Kaiser 'Eigenvalues greater than one' criterion (Field, 2009) resulted in a two-factor solution as the best adjustment for the data, accounting for $69.234 \%$ of fully explained variance. Factor 1 consists of items 1, 2, 4, 5 and 8 and explains $56,989 \%$ of the total variance (Eigenvalue of 3.753); Factor 2 consists of items 3, 6, 7 and 9, explaining $12.245 \%$ of the total variance (Eigenvalue of 3.052).

Additionally, all nine items meet the criteria for psychometrically sound items (Table 2). The structure coefficients ranged from 0.89 to 0.90 and the commonality coefficients ranged from 0.62 to 0.77. Correlations between items ranged from 0.57 to 0.76 . These items were reliable as a single dimension $(\alpha=0.904)$ (if any item were excluded, the alpha value would not decrease) and as twofactor dimensions (Factor $1 \alpha=0.878$; Factor $2 \alpha=0.842$ ).

Table 2. Explanatory Factor Analysis Results for the FCV-19S-FL

\begin{tabular}{|c|c|c|c|c|c|c|c|c|c|c|}
\hline Items & & $L D 1$ & $L D 2$ & $h^{2}$ & $M$ & $D P$ & $S_{k w}$ & $K_{r t}$ & Min & $\operatorname{Max}$ \\
\hline Item 1 & Fear of COVID-19 & 0.84 & & 0.72 & 3.33 & 1.08 & -0.20 & $-0,76$ & 1 & 5 \\
\hline Item 2 & Discomfort in class & 0.70 & & 0.70 & 2.76 & 1.28 & 0,20 & -1.4 & 1 & 5 \\
\hline Item 3 & Wet/cold hands in class & & 0.81 & 0.67 & 1.87 & 1.14 & 1,09 & 0.14 & 1 & 5 \\
\hline Item 4 & Fear of contagion & 0.85 & & 0.77 & 3.42 & 1.21 & -0.34 & -0.84 & 1 & 5 \\
\hline Item 5 & $\begin{array}{l}\text { Anxiety caused by news stories of } \\
\text { an outbreak at the university }\end{array}$ & 0.69 & & 0.62 & 3.09 & 1.31 & -0.19 & -1.13 & 1 & 5 \\
\hline Item 6 & Sleeping difficulty & & 0.83 & 0.72 & 1.67 & 1.03 & 1.53 & 1.63 & 1 & 5 \\
\hline Item 7 & Tachycardia in class & & 0.65 & 0.63 & 2.14 & 1.21 & 0.77 & -0.46 & 1 & 5 \\
\hline Item 8 & $\begin{array}{l}\text { Discomfort in classes with practical } \\
\text { activities }\end{array}$ & 0.68 & & 0.67 & 2.73 & 1.33 & 0.13 & -1.20 & 1 & 5 \\
\hline Item 9 & Difficulty concentrating in class & & 0.76 & 0.74 & 1.96 & 1.14 & 1.03 & 0.13 & 1 & 5 \\
\hline Total & FCV-19S-PL & & & & 22.3 & 8.12 & & & & \\
\hline Factor 1 & Items $1,2,4,5,8$ items & \multicolumn{2}{|c|}{ Emotional fear } & & 15.33 & 5.10 & & & & \\
\hline Factor 2 & Items $3,6,7,9$ & \multicolumn{2}{|c|}{ Cognitive fear } & & 7.66 & 3.72 & & & & \\
\hline
\end{tabular}

Notes: $L D=$ structure coefficients, $h^{2}=$ extracted communality coefficients, $M=$ mean, $S D=$ standard deviation; $S_{k w}=$ skewness, $K_{r t}=$ kurtosis; Min = minimum, Max = maximum. 


\section{Psychometric properties of the FCV-19S-FL in Brazil, France, Paraguay, and England}

The Brazilian Portuguese version was based on 253 individuals and maintained the factor structure of the European Portuguese version, with similar psychometric properties that confirm a high internal consistency, with Cronbach's Alpha of 0.907 for both subscales, respectively, and 0.937 for the total scale. Similarly, the results obtained in Paraguay with 112 individuals showed Cronbach's Alpha values ranging between 0.901 and 0.917 for both subscales and 0.939 for the total scale. The results obtained in England with a total of 40 individuals also confirm a high internal consistency of the scale, with Cronbach's Alpha between 0.851 and 0.858 for both subscales, and 0.905 for the total scale. The results obtained in France in 266 individuals presented Cronbach's Alpha values between 0.768 and 0.858 for both subscales and 0.866 for the total scale.

\section{DISCUSSION}

The present study aimed to adapt and validate the Fear of COVID-19 Scale for Face-to-Face Learning (FCV-19S-FL), in a sample of Portuguese university students following a blended learning model (online theoretical classes and face-to-face practical classes) during the COVID-19 pandemic.

Contrary to the results obtained by Ahorsu et al., (2020), who assessed the unidimensionality of the scale, the exploratory factor analysis of our study yielded a two-factor solution as the best fit for the data, which explained $69.234 \%$ of the total variance. Despite the adaptation of items 2 to 7 of the Fear of COVID-19 Scale to the context of face-to-face learning, and the introduction of items 8 and 9, the results yielded a factor structure similar to that of Tzur Bitan et al. (2020), representing emotional fear reactions (Factor 1) and symptomatic expressions of fear (factor 2), cognitive fear, and emotional fear (Magano et al., 2021). Thus, similarly to Magano et al. (2021), we named Factor 1, composed of items 1, 2, 4, 5 and 8 as Emotional Fear; Factor 2, composed of items 3, 6, 7 and 9 as of Cognitive Fear.

The reliability analysis of the FCV-19S-FL in this sample showed Cronbach's Alpha of 0.904 for the total scale, which is a better outcome than that obtained in the study of the original scale (Ahorsu et al., 2020), as well as in its adaptations to several countries (Alyami et al., 2020; Martínez-Lorca et al., 2020; Reznik et al., 2020; Sakib et al., 2020; Satici et al., 2020; Soraci et al., 2020), including Portugal (Magano et al., 2021). The same is true for Factor $1(\alpha=0.878)$ and Factor $2(\alpha=0.842)$, with values higher than those obtained by Tzur Bitan et al., (2020) and Magano et al., (2021).

The Brazilian Portuguese, French, Spanish (for Paraguay) and British English versions of the FCV19S-FL were administered in Brazil, France, Paraguay and England and maintain the factorial structure of the Portuguese version, also showing high values of Cronbach's Alpha for the full scale as well as for both factors, confirming the robustness of the instrument.

Taking into account the unpredictability of the COVID-19 pandemic regarding duration and evolution, which required the maintenance of mitigation measures, such as halting face-to-face teaching or introducing blended teaching, the FCV-19S-FL may be considered a valuable instrument to evaluate fear and worries related to in-class learning in the context of the COVID-19 pandemic. It can also be useful for the development of intervention strategies in order to reduce the impact of COVID-19 on university students.

\section{Study limitations}

The different results regarding sex in the Portuguese sample did not enable a reliable comparative analysis between groups. Notably, the study sample was collected at different stages of the academic year in Europe and South America, (i.e., at the beginning in Europe and the end in South America); 
furthermore, the pandemic was at different phases in the studied countries (i.e., Europe was facing the second COVID-19 wave). As a consequence, data could not be collected in Italy and the number of respondents in the English sample was drastically reduced, as these countries had implemented lockdown and educational institutions provided online classes exclusively. However, all versions of the FCV-19S-FL have been attached, noting that the Italian version has not been validated so far.

\section{REFERENCES}

Ahorsu, D. K., Lin, C. Y., Imani, V., Saffari, M., Griffiths, M. D., \& Pakpour, A. H. (2020). The Fear of COVID-19 Scale: Development and initial validation. International Journal of Mental Health and Addiction. https://doi.org/10.1007/s11469-020-00270-8

Al-Rabiaah, A., Temsah, M. H., Al-Eyadhy, A. A., Hasan, G. M., Al-Zamil, F., Al-Subaie, S., Alsohime, F., Jamal, A., Alhaboob, A., Al-Saadi, B., \& Somily, A. M. (2020). Middle East Respiratory Syndrome-Corona Virus (MERS-CoV) associated stress among medical students at a university teaching hospital in Saudi Arabia. Journal of Infection and Public Health, 13(5), 687691. https://doi.org/10.1016/j.jiph.2020.01.005

Alyami, M., Henning, M., Krägeloh, C. U., \& Alyami, H. (2020). Psychometric evaluation of the Arabic Version of the Fear of COVID-19 Scale. International Journal of Mental Health and Addiction, 22-30. https://doi.org/10.1007/s11469-020-00316-X

Araújo, F. J. de O., Lima, L. S. A. de, Cidade, P. I. M., Nobre, C. B., \& Neto, M. L. R. (2020). Impact of sars-cov-2 and its reverberation in global higher education and mental health. Psychiatry Research, 288(March), 112977. https://doi.org/10.1016/j.psychres.2020.112977

Bourion-Bédès, S., Tarquinio, C., Batt, M., Tarquinio, P., Lebreuilly, R., Sorsana, C., Legrand, K., Rousseau, H., \& Baumann, C. (2021). Psychological impact of the COVID-19 outbreak on students in a French region severely affected by the disease: results of the PIMS-CoV 19 study. Psychiatry Research, 295. https://doi.org/10.1016/j.psychres.2020.113559

Cao, W., Fang, Z., Hou, G., Han, M., Xu, X., Dong, J., \& Zheng, J. (2020). The psychological impact of the COVID-19 epidemic on college students in China. Psychiatry Research, 287(March), 112934. https://doi.org/10.1016/j.psychres.2020.112934

Dhar, B. K., Ayittey, F. K., \& Sarkar, S. M. (2020). Impact of COVID-19 on Psychology among the University Students. Global Challenges, 4(11), 2000038. https://doi.org/10.1002/gch2.202000038

Faro, A., Santos da Silva, L., Santos, N., D., \& Feitosa, A. L. (2020). Adaptation and validation of The Fear of COVID-19 Scale. Scielo Reprints. https://doi.org/https://doi.org/10.1590/SciELOPreprints.898

Hacımustafaoğlu, M. (2020). COVID-19 and re-opening of schools: Opinions with scientific evidence COVID-19 ve okulların açılması: Bilimsel kanıtlar eşliğinde görüşler. https://doi.org/10.14744/TurkPediatriArs.2020.90018

Kaparounaki, C. K., Patsali, M. E., Mousa, D. P. V., Papadopoulou, E. V. K., Papadopoulou, K. K. K., \& Fountoulakis, K. N. (2020). University students' mental health amidst the COVID-19 quarantine in Greece. Psychiatry Research, 290, 11311. https://doi.org/10.1016/j.psychres.2020.113111

Kecojevic, A., Basch, C. H., Sullivan, M., \& Davi, N. K. (2020). The impact of the COVID-19 epidemic on mental health of undergraduate students in New Jersey, cross-sectional study. PLoS ONE, 15(9 September), 1-16. https://doi.org/10.1371/journal.pone.0239696

Magano, J., Vidal, D. G., Sousa, H. F. P., Pimenta Dinis, M. A., \& Leite, Â. (2021). Validation and psychometric properties of the portuguese version of the coronavirus anxiety scale (Cas) and fear of covid-19 scale (fcv-19s) and associations with travel, tourism and hospitality. International 
Journal of Environmental Research and Public Health, 18(2), 1-14. https://doi.org/10.3390/ijerph18020427

Marelli, S., Castelnuovo, A., Somma, A., Castronovo, V., Mombelli, S., Bottoni, D., Leitner, C., Fossati, A., \& Ferini-Strambi, L. (2020). Impact of COVID-19 lockdown on sleep quality in university students and administration staff. Journal of Neurology, 0123456789. https://doi.org/10.1007/s00415-020-10056-6

Martínez-lorca, M., Martínez-lorca, A., Criado-Álvarez, J., Cabañas, D., \& Latorre, J. (2020). The fear of COVID-19 scale : Validation in spanish university students. Psychiatry Research, 293, 17. https://www.ncbi.nlm.nih.gov/pmc/articles/PMC7396130/pdf/main.pdf

Nathan, N., Prevost, B., Sileo, C., Richard, N., Berdah, L., Thouvenin, G., Aubertin, G., Lecarpentier, T., Schnuriger, A., Jegard, J., Guellec, I., Taytard, J., \& Corvol, H. (2020). Clinical medicine the wide spectrum of covid-19 clinical presentation in children. Journal of Clinical Medicine, 9, 2950. https://doi.org/10.3390/jcm9092950

Odriozola-González, P., Planchuelo-Gómez, Á., Jesús Irurtia, M., \& Luis-Garcia, R. de. (2020). Psychological effects of the COVID-19 outbreak and lockdown among students. Psychiatry Research, 290(January), 113180.

Paltiel, A. D., Zheng, A., \& Walensky, R. P. (2020). Assessment of SARS-CoV-2 screening strategies to permit the safe reopening of college campuses in the United States. JAMA Network Open, 3(7), e2016818. https://doi.org/10.1001/jamanetworkopen.2020.16818

Pang, N. T. P., Kamu, A., Hambali, N. L. B., Mun, H. C., Kassim, M. A., Mohamed, N. H., Ayu, F., Rahim, S. S. S. A., Omar, A., \& Jeffree, M. S. (2020). Malay version of the fear of COVID-19 scale: validity and reliability. International Journal of Mental Health and Addiction. https://doi.org/10.1007/s11469-020-00355-4

Phelan, A. L., Katz, R., \& Gostin, L. O. (2020). The novel coronavirus originating in Wuhan, China: Challenges for global health governance. JAMA - Journal of the American Medical Association, 323(8), 709-710. https://doi.org/10.1001/jama.2020.1097

Reznik, A., Gritsenko, V., Konstantinov, V., Khamenka, N., \& Isralowitz, R. (2020). COVID-19 fear in eastern europe: Validation of the fear of COVID-19 scale. International Journal of Mental Health and Addiction. https://doi.org/10.1007/s11469-020-00283-3

Sakib, N., Bhuiyan, A. K. M. I., Hossain, S., Al Mamun, F., Hosen, I., Abdullah, A. H., Sarker, M. A., Mohiuddin, M. S., Rayhan, I., Hossain, M., Sikder, M. T., Gozal, D., Muhit, M., Islam, S. M. S., Griffiths, M. D., Pakpour, A. H., \& Mamun, M. A. (2020). psychometric validation of the bangla fear of COVID-19 scale: Confirmatory factor analysis and rasch analysis. International Journal of Mental Health and Addiction. https://doi.org/10.1007/s11469-020-00289-x

Satici, B., Gocet-Tekin, E., Deniz, M. E., \& Satici, S. A. (2020). Adaptation of the fear of COVID19 scale: Its association with psychological distress and life satisfaction in turkey. International Journal of Mental Health and Addiction. https://doi.org/10.1007/s11469-020-00294-0

Shigemura, J., Ursano, R. J., Morganstein, J. C., Kurosawa, M., \& Benedek, D. M. (2020). Public responses to the novel 2019 coronavirus (2019-nCoV) in Japan: Mental health consequences and target populations. Psychiatry and Clinical Neurosciences, 74(4), 281-282. https://doi.org/10.1111/pcn.12988

Soraci, P., Ferrari, A., Abbiati, F. A., Fante, E. Del, De Pace, R., Urso, A., \& Griffiths, M. D. (2020). Validation and psychometric evaluation of the italian version of the fear of COVID-19 scale. International Journal of Mental Health and Addiction. https://doi.org/10.1007/s11469-02000277-1

Tzur Bitan D, Grossman-giron A, Bloch Y, Mayer Y, \& Shi N. (2020). Fear of COVID-19 scale: Psychometric characteristics, reliability and validity in the Israeli population. Psychiatry Research 289(January), 1-5. https://doi.org/10.1016/j.psychres.2020.113100

UNESCO. (2020). UNESCO covid-19 education response: how many students are at risk of not 
returning to school? advocacy paper - unesco biblioteca digital. 2020, July, 22. https://unesdoc.unesco.org/ark:/48223/pf0000373992

Vermund, S. H., \& Pitzer, V. E. (2020). Asymptomatic transmission and the infection fatality risk for COVID-19: Implications for school reopening. Clinical Infectious Diseases. https://doi.org/10.1093/cid/ciaa855

Walger, P., Heininger, U., Knuf, M., Exner, M., Popp, W., Fischbach, T., Trapp, S., Herr, C., \& Simon, A. (2020). become less severely ill than do adults. The vast majority of infections. GMS Hygiene and Infection Control, 15, 1-18.

WHO/Europe. (2020). International Health Regulations - 2019-nCoV outbreak is an emergency of international concern. https://www.euro.who.int/en/health-topics/healthemergencies/international-health-regulations/news/news/2020/2/2019-ncov-outbreak-is-anemergency-of-international-concern

World Health Organization - WHO. (n.d.). WHO Coronavirus Disease (COVID-19) Dashboard. WHO. Retrieved February 8, 2021, from https://covid19.who.int/

Wrighton, M. S., \& Lawrence, S. J. (2020). Reopening colleges and universities during the COVID19 pandemic. Annals of Internal Medicine, 173(8), 664-665. https://doi.org/10.7326/M20-4752

Zhou, S. J., Zhang, L. G., Wang, L. L., Guo, Z. C., Wang, J. Q., Chen, J. C., Liu, M., Chen, X., \& Chen, J. X. (2020). Prevalence and socio-demographic correlates of psychological health problems in Chinese adolescents during the outbreak of COVID-19. European Child and Adolescent Psychiatry, 29(6), 749-758. https://doi.org/10.1007/s00787-020-01541-4 


\section{APPENDIX A}

European Portuguese Version

\section{Escala do Medo do COVID 19, nas Aulas Presenciais (FCV-19S-FL)}

(Maria dos Prazeres Silva Gonçalves, Josefa Maria Dias da Silva Fernandes \& Maria Manuela da Silva Leite, 2020)

Abaixo estão algumas perguntas sobre o COVID-19 e seu impacto em sua vida universitária. Leia cada frase com atenção e clique na opção que melhor descreve como você se sentiu ao voltar para a aula pessoalmente, de acordo com o diagrama a seguir:

1 - Não concordo em absoluto; 2 - Não concordo; 3 - não concordo nem discordo; 4 - Eu concordo; 5 - concordo plenamente

\begin{tabular}{|l|l|l|l|l|l|}
\hline & $\begin{array}{c}\text { Discordo } \\
\text { Totalmente }\end{array}$ & Discordo & $\begin{array}{c}\text { Nem concordo } \\
\text { nem discordo }\end{array}$ & Concordo & $\begin{array}{c}\text { Concordo } \\
\text { Totalmente }\end{array}$ \\
\hline 1. Tenho muito medo do COVID & & & & \\
\hline $\begin{array}{l}\text { 2. O regresso às aulas presenciais deixa-me } \\
\text { desconfortável }\end{array}$ & & & & & \\
\hline $\begin{array}{l}\text { 3. Durante as aulas presenciais sinto as } \\
\text { minhas mãos húmidas/frias }\end{array}$ & & & & & \\
\hline $\begin{array}{l}\text { 4. Tenho muito medo de ser contagiado na } \\
\text { faculdade }\end{array}$ & & & & & \\
\hline $\begin{array}{l}\text { 5. Fico nervoso ou ansioso sempre que } \\
\text { vejo/ouço noticias de surtos nas faculdades }\end{array}$ & & & & & \\
\hline $\begin{array}{l}\text { 6. Tenho dificuldades em dormir na noite } \\
\text { anterior às aulas presenciais }\end{array}$ & & & & & \\
\hline $\begin{array}{l}\text { 7. O meu coração dispara sempre que um } \\
\text { colega na sala de aula espirra ou tosse }\end{array}$ & & & & & \\
\hline $\begin{array}{l}\text { 8. Sinto-me desconfortável com a realização } \\
\text { de atividades (ex. laboratoriais, trabalhos de } \\
\text { grupo) que impliquem maior proximidade } \\
\text { com colegas }\end{array}$ & & & & & \\
\hline $\begin{array}{l}\text { 9. Tenho dificuldades em concentrar-me nas } \\
\text { aulas presenciais, devido ao medo de ser } \\
\text { contagiado }\end{array}$ & & & & & \\
\hline
\end{tabular}




\section{APPENDIX B}

Brazilian Portuguese Version

\section{Escala do Medo do COVID 19 para Aulas Presenciais (FCV-19S-FL)}

(Josefa Maria Dias da Silva Fernandes Fernandes, Rúbia Piccolo Verza, Karina Flavio de Carvalho, Maria dos Prazeres Silva Gonçalves \& Maria Manuela da Silva Leite, 2020)

Abaixo estão algumas perguntas sobre o impacto da COVID-19 em sua vida acadêmica. Leia cada frase com atenção e clique na opção que melhor descreve como você se sente ao retornar às aulas presenciais, de acordo com os critérios a seguir:

1 - Discordo totalmente; 2 - Discordo; 3 - Indiferente; 4 - Concordo; 5 - Concordo totalmente

\begin{tabular}{|l|l|l|l|l|l|}
\hline & $\begin{array}{c}\text { Discordo } \\
\text { Totalmente }\end{array}$ & Discordo & Indiferente & Concordo & $\begin{array}{c}\text { Concordo } \\
\text { Totalmente }\end{array}$ \\
\hline $\begin{array}{l}\text { 1. Tenho muito medo da COVID-19. } \\
\text { desconforno às aulas presenciais me deixa }\end{array}$ & & & & & \\
\hline $\begin{array}{l}\text { 3. Sinto as minhas mãos úmidas/geladas durante } \\
\text { as aulas presenciais. }\end{array}$ & & & & & \\
\hline $\begin{array}{l}\text { 4. Tenho muito medo de ser infectado(a) na } \\
\text { universidade. }\end{array}$ & & & & & \\
\hline $\begin{array}{l}\text { 5. Fico nervoso(a) ou ansioso(a) sempre que } \\
\text { vejo/ouço noticias de surtos de COVID-19 na } \\
\text { universidade. }\end{array}$ & & & & & \\
\hline $\begin{array}{l}\text { 6. Tenho dificuldade para dormir na noite } \\
\text { anterior às aulas presenciais. }\end{array}$ & & & & & \\
\hline $\begin{array}{l}\text { 7. O meu coração dispara sempre que um(a) } \\
\text { colega espirra ou tosse na sala de aula. }\end{array}$ & & & & & \\
\hline $\begin{array}{l}\text { 8. Não me sinto confortável durante atividades } \\
\text { que impliquem maior proximidade entre colegas } \\
\text { (e.g. laboratoriais e trabalhos em grupo). }\end{array}$ & & & & & \\
\hline $\begin{array}{l}\text { 9. Tenho dificuldade em me concentrar nas } \\
\text { aulas presenciais devido ao medo de ser } \\
\text { infectado(a). }\end{array}$ & & & & & \\
\hline
\end{tabular}




\section{APPENDIX C}

French Version

\section{Échelle de peur COVID 19 dans les classes en face à face (FCV-19S-FL) (Maria dos Prazeres Silva Gonçalves, Josefa Maria Dias da Silva Fernandes \& Maria Manuela da Silva Leite, 2020)}

Vous trouverez ci-dessous quelques questions concernant la COVID-19 et son impact sur votre vie universitaire. Lisez attentivement chaque phrase et cliquez sur l'option qui décrit le mieux ce que vous ressentiez relativement au retour en classe en présentiel, selon le schéma suivant:

1 - Je ne suis pas du tout d'accord; 2 - Je ne suis pas d'accord ; 3 - Je ne suis ni d'accord ni en désaccord; 4 - Je suis d'accord; 5 - Je suis entièrement d'accord

\begin{tabular}{|c|c|c|c|c|c|}
\hline & $\begin{array}{l}\text { Je ne } \\
\text { suis pas } \\
\text { du tout } \\
\text { d'accord }\end{array}$ & $\begin{array}{l}\text { Je ne } \\
\text { suis pas } \\
\text { d'accord }\end{array}$ & $\begin{array}{l}\text { Je ne suis } \\
\text { ni d'accord } \\
\text { ni en } \\
\text { désaccord }\end{array}$ & $\begin{array}{l}\text { Je suis } \\
\text { d'accord }\end{array}$ & $\begin{array}{l}\text { Je suis } \\
\text { entièrement } \\
\text { d'accord }\end{array}$ \\
\hline 1. J'ai très peur de la COVID-19 & & & & & \\
\hline $\begin{array}{l}\text { 2. Le retour aux cours em présentiel me rend mal à } \\
\text { l'aise }\end{array}$ & & & & & \\
\hline $\begin{array}{l}\text { 3. Pendant les cours présentiel, je sens mes mains } \\
\text { moites/froides }\end{array}$ & & & & & \\
\hline 4. J'ai très peur d'être contaminé(e) à l'université & & & & & \\
\hline $\begin{array}{l}\text { 5. Je deviens nerveux ou anxieux chaque fois que je } \\
\text { vois/entends parler de nouveaux cas à l'université }\end{array}$ & & & & & \\
\hline $\begin{array}{l}\text { 6. J'ai du mal à dormir la veille des cours em } \\
\text { présentiel }\end{array}$ & & & & & \\
\hline $\begin{array}{l}\text { 7. Mon cœur bat la chamade chaque fois qu'un } \\
\text { camarade de classe éternue ou tousse }\end{array}$ & & & & & \\
\hline $\begin{array}{l}\text { 8. Je ne me sens pas à l'aise d'effectuer des activités } \\
\text { qui impliquent une plus grande proximité avec mes } \\
\text { camarades (par exemple, laboratoire, travail de } \\
\text { groupe) }\end{array}$ & & & & & \\
\hline $\begin{array}{l}\text { 9. J'ai eu du mal à me concentrer sur les cours } \\
\text { présentiel, par peur d'être infecté }\end{array}$ & & & & & \\
\hline
\end{tabular}




\section{APPENDIX D}

British English Version

\section{Fear of COVID-19 Scale for Face-to-Face Learning (FCV-19S-FL)}

(Aline Bonfim Pessoto, Marineide Pina-Zallio, Josefa Maria Dias da Silva Fernandes, Maria dos Prazeres Silva Gonçalves \& Maria Manuela da Silva Leite, 2020)

Below are some questions about the impact of COVID-19 on your academic life. Read each sentence carefully and select the option that best explains how you feel about returning to face-to-face classes, according to the following criteria:

1- Strongly disagree, 2- Disagree, 3- Neither agree nor disagree, 4- Agree, 5- I totally agree

\begin{tabular}{|l|l|l|l|l|l|}
\hline & $\begin{array}{l}\text { Strongly } \\
\text { disagree }\end{array}$ & Disagree & $\begin{array}{l}\text { Neither agree } \\
\text { nor disagree }\end{array}$ & Agree & $\begin{array}{l}\text { I totally } \\
\text { agree }\end{array}$ \\
\hline 1. I am very afraid of COVID-19. & & & & & \\
\hline $\begin{array}{l}\text { 2. Returning to face-to-face classes makes me } \\
\text { uncomfortable. }\end{array}$ & & & & & \\
\hline $\begin{array}{l}\text { 3. I feel my hands wet/cold during face-to-face } \\
\text { classes. }\end{array}$ & & & & & \\
\hline $\begin{array}{l}\text { 4. I am very afraid of being infected at the } \\
\text { university. }\end{array}$ & & & & & \\
\hline $\begin{array}{l}\text { 5. I get nervous or anxious whenever I watch/hear } \\
\text { news stories of an outbreak at the university. }\end{array}$ & & & & & \\
\hline $\begin{array}{l}\text { 6. I have difficulty sleeping the night before face- } \\
\text { to-face classes. }\end{array}$ & & & & & \\
\hline $\begin{array}{l}\text { 7. My heart beats too fast whenever a classmate } \\
\text { sneezes or coughs. }\end{array}$ & & & & & \\
\hline $\begin{array}{l}\text { 8. I feel uncomfortable with activities that imply } \\
\text { greater physical proximity to my fellow students } \\
\text { (e.g. laboratory and group work). }\end{array}$ & & & & & \\
\hline $\begin{array}{l}\text { 9. I have difficulty concentrating in face-to-face } \\
\text { classes due to the fear of being infected. }\end{array}$ & & & & & \\
\hline
\end{tabular}




\section{APPENDIX E \\ Spanish Version (for Paraguay)}

\section{Escala de miedo COVID 19 en las clases presenciales (FCV-19S-FL)}

(Lívia Ribeiro Severino, Maria dos Prazeres Silva Gonçalves, Maria Manuela da Silva Leite \& Josefa Maria Dias da Silva Fernandes, 2020)

Abajo son presentados algunas cuestiones en relación al COVID-19 y al su impacto en su vida académica. Lea atentamente cada una de las frases y haga clic en las mejor opciones que describen lo que se sintió al volver a las clases presenciales, de acuerdo con el siguiente esquema:

1-Muy en el desacuerdo, 2- Desacuerdo, 3- Ni de acuerdo, ni en desacuerdo, 4- Estoy de acuerdo, 5Concuerdo totalmente

\begin{tabular}{|c|c|c|c|c|c|}
\hline & $\begin{array}{l}\text { Muy en el } \\
\text { desacuerdo }\end{array}$ & Desacuerdo & $\begin{array}{l}\text { Ni de } \\
\text { acuerdo, ni } \\
\text { en } \\
\text { desacuerdo }\end{array}$ & $\begin{array}{l}\text { Estoy de } \\
\text { acuerdo }\end{array}$ & $\begin{array}{l}\text { Concuerdo } \\
\text { totalmente }\end{array}$ \\
\hline 1. Tengo mucho miedo del COVID-19 & & & & & \\
\hline 2. El regreso a clases presenciales me incomoda & & & & & \\
\hline $\begin{array}{l}\text { 3. Durante las clases presenciales siento mis } \\
\text { manos están mojadas/ frías }\end{array}$ & & & & & \\
\hline $\begin{array}{l}\text { 4. Tengo mucho miedo de infectarme en la } \\
\text { Universidad }\end{array}$ & & & & & \\
\hline $\begin{array}{l}\text { 5. Me pongo nervioso o ansioso cada vez que veo } \\
\text { / escucho noticias de brotes en las universidades }\end{array}$ & & & & & \\
\hline $\begin{array}{l}\text { 6. Tengo dificultad en dormir en la noche anterior } \\
\text { a clases presenciales }\end{array}$ & & & & & \\
\hline $\begin{array}{l}\text { 7. Mi corazón acelera siempre que un colega de } \\
\text { clase estornuda o tose }\end{array}$ & & & & & \\
\hline $\begin{array}{l}\text { 8. Mi siento incómodo al realizar actividades que } \\
\text { implican una mayor proximidad a los compañeros } \\
\text { (Ejemplos: laboratorio, trabajo en grupo) }\end{array}$ & & & & & \\
\hline $\begin{array}{l}\text { 9. Tengo dificultades de concentrarme en las } \\
\text { clases presenciales por miedo de infectarme }\end{array}$ & & & & & \\
\hline
\end{tabular}




\section{APPENDIX F \\ Italian Version}

\section{COVID 19 Fear Scale nelle classi faccia a faccia (FCV-19S-FL)}

(Pauline Scrocchio Romero, Josefa Maria Dias da Silva Fernandes, Maria Manuela da Silva Leite \& Maria dos Prazeres Silva Gonçalves, 2020)

In basso sono rappresentate alcune domande rispetto al COVID-19 e al suo impatto nella tua vita universitaria. Leggi con attenzione ognuna delle frasi a clicca l'opzione che meglio spiega la tua sensazione nel ritorno alle lezioni didattiche con presenza:

1-Sono totalmente disaccordo 2-Disaccordo 3-Non sono d'accordo/Disaccordo 4-Sono d'accordo 5-Sono totalmente d'accordo

\begin{tabular}{|c|c|c|c|c|c|}
\hline & $\begin{array}{l}\text { Sono } \\
\text { totalmente } \\
\text { disaccordo }\end{array}$ & Disaccordo & $\begin{array}{l}\text { Non sono } \\
\text { d'accordo/ } \\
\text { Disaccordo }\end{array}$ & $\begin{array}{l}\text { Sono } \\
\text { d'accordo }\end{array}$ & $\begin{array}{l}\text { Sono } \\
\text { totalmente } \\
\text { d'accordo }\end{array}$ \\
\hline 1.Ho molta paura del COVID-19 & & & & & \\
\hline $\begin{array}{l}\text { 2. Ritornare alle lezioni in presenza mi } \\
\text { lascia sconfortato }\end{array}$ & & & & & \\
\hline $\begin{array}{l}\text { 3. Durante le lezioni in presenza sento le } \\
\text { mie mani sudate e fredde. }\end{array}$ & & & & & \\
\hline $\begin{array}{l}\text { 4. Ho molta paura di essere contagiato } \\
\text { nell'ambiente Universitario }\end{array}$ & & & & & \\
\hline $\begin{array}{l}\text { 5. Sono nervoso e ansioso quando } \\
\text { apprendo notizie di focolai nell'ambiente } \\
\text { universitario }\end{array}$ & & & & & \\
\hline $\begin{array}{l}\text { 6. Ho difficoltà nel sonno il giorno prima } \\
\text { delle lezioni in presenza }\end{array}$ & & & & & \\
\hline $\begin{array}{l}\text { 7. Il mio cuore accelera i battiti quando } \\
\text { un mio collega nell'aula starnutisce o } \\
\text { tossisce }\end{array}$ & & & & & \\
\hline $\begin{array}{l}\text { 8. Non sono a mio agio in relazione alle } \\
\text { attività con che includono avvicinamento } \\
\text { ai colleghi (es. laboratorio, attività in } \\
\text { gruppo) }\end{array}$ & & & & & \\
\hline $\begin{array}{l}\text { 9. Ho molta difficoltà di concentrazione } \\
\text { durante le lezioni in presenza dovuto alla } \\
\text { paura di essere contagiato. }\end{array}$ & & & & & \\
\hline
\end{tabular}

